\title{
Pharmacological Studies of Cordia salicifolia Cham in Normal and Diabetic Rats
}

\author{
Vera Lúcia Dias Siqueira, Diógenes Aparicio Garcia Cortez, Carlos Eduardo de Oliveira, \\ Celso Vataru Nakamura and Roberto Barbosa Bazotte* \\ Department of Pharmacy and Pharmacology and Department of Clinical Analysis, State University of Maringa, Av. \\ Colombo 5790, 87020-900, Maringa - PR - Brasil
}

\begin{abstract}
The anti-obesity, appetite suppressant, diuretic and hipolipidemic effect of dried powdered leaves of $\underline{\text { Cordia }}$ salicifolia Cham (CS) were investigated. CS $\left(20 \mathrm{mg} \mathrm{kg}^{-1}\right.$. day $\left.{ }^{-1}\right)$ dissolved in water was daily administered by gavage during 13 days. In contrast with the popular use as anti-obesity, appetite suppressant and diuretic, no effect were detected. However, hipolipidemic effect was observed in normal and alloxan-diabetic rats.
\end{abstract}

Key words: Herbal therapies, hipolipidemic activity, porangaba, Cordia salicifolia

\section{INTRODUCTION}

Cordia salicifolia Cham (CS) can be found not only in Brazil but also in tropical forest areas of Argentina and Paraguay. This plant belongs to the family Boraginaceae. In Brazil, it is commonly called porangaba, chá de bugre and café do mato. $C S$ is a very popular herb, used by the Brazilian population as diuretic, appetite suppressant and weight loss product (Cruz, 1995). The partially purified extract from whole plant showed an inhibitory effect on herpes simplex virus type 1 (Hayashi et al., 1990). The methanolic extract of the branches and leaves showed cytotoxic activity against cancer cells (Arisawa et al., 1994). In addition, research with rabbits and guinea pigs indicated cardiotonic properties (Matsunaga et al., 1997). However, there is no research in humans or animal models showing the putative diuretic, appetite suppressant and/or anti-obesity effect of $C S$. Thus, the present work was designed to study these aspects and the hipolipidemic activity of $C S$. For this purpose, a suitable animal model, i.e., normal and alloxan-diabetic rats were employed.

\section{MATERIALS AND METHODS}

\section{Plant material}

Dried powdered leaves (Lot L1110070) manufactured under the highest quality control were obtained.

\section{Animals}

Male Wistar rats weighing about $200 \mathrm{~g}$, were individually caged in an environment in which the photoperiod and temperature were controlled. Food and water were freely available. The manipulation of the animals followed the Brazilian Law on the protection of animals. Two animal model, i.e., normal and diabetic rats were employed.

\footnotetext{
${ }^{*}$ Author for correspondence
} 
Normal rats. Rats that received CS (experimental group) or water (control group) at 5:00 pm, during 13 days were employed. For experimental purpose $C S$ was dissolved in water. The amount $\left(20 \mathrm{mg} \cdot \mathrm{kg}^{-}\right.$ ${ }^{1}$. day $^{-1}$ ) and administration (orally) of CS imitate the popular use to treat obesity in Brazil.

Diabetic rats. Overnight fasted rats received iv, alloxan $\left(40 \mathrm{mg} \cdot \mathrm{kg}^{-1}\right)$ dissolved in saline. Five days after alloxan administration all diabetic animals with glycemia (Bergmeyer and Bernt, 1974) greater than $300 \mathrm{mg} . \mathrm{dL}^{-1}$ started the treatment with $C S$ or water (control group).

\section{Anti-obesity, appetite suppressant and diuretic activity}

The anti-obesity, appetite suppressant and diuretic activity of $C S$ were based in the effect on body weight, daily food ingestion and daily urine elimination, respectively. These parameters were measured on day $1,3,5,7,9$ and 13 after starting the treatment with $C S$ or water (control group).

\section{Hipolipidemic activity}

On day 13 (at 5:00 p.m.) immediately after the administration of $C S$ or water (control group) food was withdrawn and the rats were killed by decapitation $15 \mathrm{~h}$ later. Blood was immediately collected, centrifuged and the separated serum was frozen for further assaying of cholesterol (Allain et al., 1974) and triglycerides (Bucolo and David, 1973).

\section{Statistical Analysis}

The program GraphPad Prism (version 2.0) was used to calculate the mean \pm SEM. Data were analysed statistically by the unpaired Student- $t$ test. A $95 \%$ level of confidence $(\mathrm{P}<0.05)$ was accepted for all comparisons.

\section{RESULTS AND DISCUSSION}

There are few studies showing the effectiveness of herbal therapy for management of obesity (Bhatt et al., 1995; Andersen and Fogh, 2001; Sindler, 2001). In contrast with these studies, data obtained showed clearly that $C S$ orally-administered during 13 days did not affect the rate of body weight gain (Table 1A), daily food ingestion (Table 1B), daily water ingestion (not showed) and daily urine elimination (Table 1C). Therefore, the popular reputation of $C S$ as diuretic, appetite suppressant and weight loss product (Cruz, 1995), were not found. The absence of effects strongly suggested that $C S$ did not have anti-obesity effect. On the other hand, $C S$ reduced $(\mathrm{p}<0.05)$ the blood levels of triglycerides but did not affect cholesterolemia (Table 2) and glycemia (not showed). Because the hypotriglyceridemic effect of $C S$ was obtained from rats with normal levels of triglycerides we decided to repeat these experiments using an experimental model of hypertriglyceridemia, i.e., alloxan diabetic rats.

Table 1 - Effect of Cordia salicifolia Cham (CS) on body weight (1A), daily food intake (1B), and daily urine elimination (IC). During 13 days the rats received CS (CS group) orally administered $\left(20 \mathrm{mg}^{\mathrm{kg}} \mathrm{kg}^{-1} \cdot \mathrm{day}^{-1}\right)$ or an equal volume of $\mathrm{H}_{2} \mathrm{O}$ (C group). All parameters were measured on day 1, 3, 5, 7, 9 and 13.

\section{A - Body Weight (g)}

\begin{tabular}{|c|c|c|c|c|c|c|}
\hline Groups & Day 1 & Day 3 & Day 5 & Day 7 & Day 9 & Day 13 \\
\hline $\mathbf{C}$ & $197.8 \pm 2.0$ & $207.8 \pm 2.0$ & $222.3 \pm 2.3$ & $236.0 \pm 4.1$ & $229.0 \pm 2.3$ & $237.8 \pm 2.4$ \\
\hline CS & $201.6 \pm 1.5$ & $211.8 \pm 2.0$ & $225.3 \pm 2.7$ & $235.4 \pm 3.1$ & $228.2 \pm 2.25$ & $237.0 \pm 2.6$ \\
\hline \multicolumn{7}{|c|}{ 1B - Daily Food Intake (g) } \\
\hline Groups & Day 1 & Day 3 & Day 5 & Day 7 & Day 9 & Day 13 \\
\hline $\mathrm{C}$ & $26.9 \pm 1.2$ & $27.2 \pm 1.2$ & $24.8 \pm 0.9$ & $25.3 \pm 1.0$ & $21.9 \pm 2.0$ & $25.5 \pm 0.7$ \\
\hline CS & $25.5 \pm 3.5$ & $26.3 \pm 2.7$ & $22.9 \pm 4.2$ & $23.0 \pm 3.5$ & $25.7 \pm 3.1$ & $25.9 \pm 2.2$ \\
\hline \multicolumn{7}{|c|}{ 1C - Daily Urine Elimination $(\mathrm{mL})$} \\
\hline Groups & Day 1 & Day 3 & Day 5 & Day 7 & Day 9 & Day 13 \\
\hline $\mathrm{C}$ & $6.1 \pm 0.4$ & $4.5 \pm 0.7$ & $9.1 \pm 0.7$ & $8.3 \pm 0.9$ & $11.0 \pm 0.9$ & $8.4 \pm 0.7$ \\
\hline CS & $5.6 \pm 0.7$ & $3.8 \pm 0.4$ & $7.8 \pm 0.8$ & $10.6 \pm 1.0$ & $10.6 \pm 1.1$ & $9.8 \pm 1.0$ \\
\hline
\end{tabular}

The results (mean \pm SEM of 9 rats ) were compared by Student $t$ test. $\mathrm{P}>0.05$ (C vs SC). 
As shown in Table 3, the treatment with $C S$ orally administered during 13 days decreased $(\mathrm{p}<0.05)$ hypertriglyceridemia promoted by diabetes.

To verify if the hipolipidemic effect occurred via reversion of diabetes, the glycemia of alloxandiabetic rats orally-treated during 13 days with $C S$ was investigate.The treatment with $C S$ did not affect glycemia, suggesting that the hypolipidemic effect of $C S$ was not mediated by an amelioration of diabetes (Table 4).

Finally, althoug $C S$ not shown diuretic, appetite suppressant and weight loss effect. It could be still possible that dried powdered leaves from $C S$ might be useful in the treatment of human hyperlipidemia. But, it will be necessary further experimental and clinical studies to confirm this suggestion.

Table 2 - Effect of Cordia salicifolia Cham (CS) on blood levels of triglycerides and cholesterol. During 13 days the rats received by gavage $C S$ (CS group) $\left(20 \mathrm{mg} \cdot \mathrm{kg}^{-1}\right.$.day ${ }^{-1}$ ) or an equal volume of $\mathrm{H}_{2} \mathrm{O}$ (C group). Blood samples from 15- $\mathrm{h}$ fasted rats were collected for the measurement of triglycerides and cholesterol (mg.dL $\left.\mathrm{mL}^{-1}\right)$.

\begin{tabular}{c|c|c}
\hline Groups & Triglycerides & Cholesterol \\
\hline C & $77.4 \pm 4.1$ & $82.1 \pm 3.8$ \\
CS & $63.8^{*} \pm 5.4$ & $81.5 \pm 4.2$ \\
\hline
\end{tabular}

The results (mean \pm SEM of 8 rats) were compared by Student $\mathrm{t}$ test. $* \mathrm{P}<0.05$ (C vs SC).

Table 3 - Effect of Cordia salicifolia Cham (SC) on blood levels of triglycerides and cholesterol in diabetic rats. The experimental conditions were those described in the table 2.

\begin{tabular}{c|r|r|r}
\hline Groups & Treatment & Triglycerides & Cholesterol \\
\hline C & Before treatment & $119.8 \pm 10.8$ & $59.2 \pm 8.0$ \\
& After treatment & $115.8 \pm 7.1$ & $64.0 \pm 7.7$ \\
\hline CS & Before treatment & $118.2 \pm 19.2$ & $69.0 \pm 6.9$ \\
& After treatment & $76.1^{*} \pm 6.0$ & $63.0 \pm 8.2$ \\
\hline
\end{tabular}

The results (mean \pm SEM of 6 rats) were compared by Student $\mathrm{t}$ test. $* \mathrm{P}<0.05$. Before vs. after treatment.

Table 4 - Effect of Cordia salicifolia Cham on blood levels of glucose in diabetic rats. During 13 days the rats received Cordia salicifolia Chan (CS group) orally administered $\left(20 \mathrm{mg} \cdot \mathrm{kg}^{-1}\right.$. day $\left.{ }^{-1}\right)$ or an equal volume of $\mathrm{H}_{2} \mathrm{O}(\mathrm{C}$ group). Blood samples from fed rats were collected for the measurement of glycemia $\left(\mathrm{mg}^{\mathrm{d}} \mathrm{dL}^{-1}\right)$.

\begin{tabular}{crr}
\hline Groups & Treatment & Glycemia \\
\hline C & Before treatment & $419.6 \pm 47.2$ \\
& After treatment & $342.5 \pm 1.3$ \\
\hline CS & Before treatment & $424.9 \pm 13.7$ \\
& After treatment & $340.1 \pm 1.7$ \\
\hline
\end{tabular}

The results (mean \pm SEM of 5 rats) were compared by Student $t$ test. $\mathrm{P}>0.05$ (C vs SC).

\section{ACKNOWLEDGEMENTS}

This work was supported by by Steviafarma and CNPq (Grant number 521155/01-0).

\section{RESUMO}

$\mathrm{O}$ efeito anti-obesidade, anorexigeno, diurético e anti-hiperlipêmico de folhas secas pulverizadas de Cordia salicifolia Cham (CS) foi investigado. CS foi dissolvida em água e administrada $\left(20 \mathrm{mg} . \mathrm{Kg}^{-}\right.$
${ }^{1} . \mathrm{dia}^{-1}$ ) por gavagem durante 13 dias. A dose utilizada correspondente à empregada no Brasil. Contrariamente ao uso popular, o efeito antiobesidade, anorexigeno e diurético não foi observado. Porém, observamos efeito hipolipidêmico em ratos normais e portadores de diabetes induzidos por aloxana. 


\section{REFERENCES}

Allain, C. C.; Poon, L. S.; Chan, C. S.; Richmond, W. and $\mathrm{Fu}$, P. C. (1974), Enzymatic determination of total serum cholesterol. Clin. Chem., 20, 470-475.

Andersen, T. and Fogh, J. (2001), Weight loss and delayed gastric emptyng following a South American herbal preparation in overweight patients. J. Hum. Nutr. Diet., 14, 243-250.

Arisawa, M.; Arisawa M.; Fujita A.; Hayashi T.; Hayashi K.; Ochiai H. and Morita N. (1994), Cell growth inhibition of $\mathrm{KB}$ cells by plant extracts. Natural Medicines, 48, 338-347.

Bergmeyer, H. U. and Bernt, E. (1974), Determination of glucose with glucose oxidase and peroxidase. In: Bergmeyer, H. U. (Ed.). Methods of enzymatic analysis. New York: Verlag Chemie-Academic Press. pp. 1205-1215.

Bhatt, A. D.; Dalal, D. G.; Shah, S. J.; Joshi, B. A.; Gajjar, M. N.; Vaidya, R. A.; Vaidya, A. B. and Antarkar, D. S. (1995), Conceptual and methodologic challenges of assessing the short-term efficacy of Guggulu in obesity: data emergent from a naturalistic clinical trial. J. Postgrad. Med., 41, 5-7.

Bucolo, G. and David, H. (1973), Quantitative determination of serum triglycerides by the enzymes. Clin. Chem., 19, 476-482.
Cruz, G. L. (1995), Dicionário das plantas úteis do Brasil. 5. ed. Rio de Janeiro: Bertrand. pp. 599.

Hayashi, K.; Hayashi, T.; Morita, N. and Niwayama, S. (1990), Antiviral activity of an extract of Cordia salicifolia on herpes simplex virus type 1. Planta Medica, 56, 439-443.

Matsunaga, K.; Sasaki S. and Ohizume, Y. (1997), Excitatory and inhibitory effects of paraguayan medicinal plants Equisetum giganteum, Acanthpspermum australe, Allophylus edlis and Cordia salicifolia on contraction of rabbit aorta and guinea-pig left atrium. Natural Medicines, 51, 478-481.

Sindler, B. H. (2001), Herbal therapy for management of obesity: observations from a clinical endocrinology practice. Endocr Pract., 7, 443-447.

Received: July 12, 2004; Revised: April 18, 2005; Accepted: December 29, 2005. 